\title{
GoIng Nowhere In A HuRry? THE PACIFIC'S EPA NEGOTIATIONS WITH THE EUROPEAN UNION
}

Jane Kelsey*

This paper explores the Economic Partnership Agreement (EPA) negotiation process of the EU$A C P$ with a focus on the Pacific region. To comply with the requirements of the Cotonou Agreement 2000 and the requirements of the WTO EPAs must be negotiated before 2008. They will replace the trade arrangements between the EU and the ACP States pursuant to the Cotonou Agreement 2000. The Pacific states have proposed a creative EPA text to address their concerns about the effects of any new agreement with the EU. Professor Kelsey's view is that the Pacific 'wish list' contains two intrinsic tensions : one between its trade liberalisation and development agendas, and the other between the affirmation of sovereign integrity and supranational institutional arrangements. Moreover, the EU and the Pacific states have different trade interests and the demands made by the Pacific states have largely been rejected by the EU. The conclusion is that the production of a final text of the Pacific EPA is not imminent.

This paper was written prior to the military coup in Fiji on 5 December 2006 and does not discuss the significant implications of that event for the negotiations.

Cet article analyse le processus de négociation actuellement en cours et qui doit tendre à la signature d'un accord entre l'Union Européenne et les Pays ACP (Afrique - Caraïbe-Pacifique) et plus particulièrement lorsque les intérêts des pays du Pacifique Sud sont concernés.

Pour répondre aux conditions imposées par les Accords de Cotonou de 2000 et à celles de l'Organisation du Commerce International, de nouveaux accords de partenariat économique (APE) doivent intervenir avant 2008. Ces accords ont vocation à remplacer ceux actuellement en vigueur entre l'Union Européenne et les Pays ACP issus de l'accord de Cotonou de 2000.

* Professor, School of Law, University of Auckland, New Zealand. 
Les Etats insulaires du Pacifique ont, en vue de la signature du futur accord de partenariat économique, suggéré à l'Union Européenne, une base originale de négociation susceptible de mieux répondre à leurs préoccupations.

Selon, le Professeur Kelsey, la liste des desiderata des Pays du Pacifique révèle une double tension entre d'une part, la volonté de ces pays de tendre vers une plus grande libéralisation des échanges commerciaux tout en conciliant le respect de leur calendrier de développement et d'autre part entre la délicate articulation qu'il convient de trouver entre le respect de leur souveraineté et celui des accords internationaux.

Par ailleurs, les intérêts commerciaux des Etats du Pacifique et ceux de l'Union Européenne divergent sur bien des points la plupart des demandes formulées par les Etats du Pacifique ayant été à ce jour rejetées, un tel contexte ne laissant pas augurer d'une signature prochaine d'un accord de partenariat économique pour le Pacifique.

NB : Cet article a été rédigé avant le coup d'Etat militaire du 5 décembre 2006 à Fidji et ne prend donc pas en compte ses conséquences éventuelles sur les négociations en cours.

The Cotonou Agreement 2000 set a deadline of 31 December 2007 for the negotiation of Economic Partnership Agreements (EPA) between the European Union (EU) and various regions of the African Caribbean and Pacific (ACP) group. One year away, the prospects of that occurring in the Pacific and most other regions seem remote.

This article examines the draft text of the EPA prepared by the Pacific ACP states in June 2006, focusing on two intrinsic tensions: one between its trade liberalisation and development agendas, and the other between the affirmation of sovereign integrity and supranational institutional arrangements. A brief introduction locates these tensions in the broader Cotonou negotiations and records the challenges it is facing from governments of the South and Europe itself. This provides the context for a more detailed analysis of the structure and substance of the draft Pacific ACP text, with its combination of development-centred innovations and orthodox trade liberalisation provisions. The final section reflects on the European Commission's response and the Pacific ACP governments' reactions to that response, and what might happen as the deadline approaches. It concludes that failure to complete the EPA may provide the space for the Pacific island states to reflect on alternative ways to achieve their objectives of culturally appropriate development and sovereign integrity. 


\section{THE CONTEXT OF THE EPA NEGOTIATIONS}

In 1996 a European Union (EU) green paper proposed the renegotiation of the trade preferences granted to ACP countries under the Lomé conventions. ${ }^{1}$ This was prompted by three main considerations. First, new priorities were driving the Europeans' foreign and economic policy agenda. While Africa remained of major importance, the historical colonial commitments to Caribbean and Pacific states were not. ${ }^{2}$ Second, development strategies based on trade preferences had been overtaken by a new orthodoxy that advocated trade liberalisation as the pathway to exportled development. Third, the new rules governing disputes at the World Trade Organisation (WTO) meant the EU could no longer veto the adoption of findings that the Lomé preferences were in breach of its most favoured nation (MFN) obligations under the General Agreement on Tariffs and Trade (GATT). ${ }^{3}$ A series of complaints against EU preferences on banana imports from the ACP states began in the WTO in $1995,{ }^{4}$ and culminated in January 2001 with the adoption of the Appellate Body's finding that the EU had not complied with previous rulings. The European Commission (EC) negotiated a temporary waiver of compliance to expire on 31 December 2007.5

The terms for this renegotiation are found in the Cotonou Agreement 2000. It is replete with references to partnership and development, but the timeframe, content and model of regionally based liberalisation were all driven by the European side. The EC effectively divided the 75 ACP states into six sub-groups, of which the Pacific is one. It justified this by arguing that each subgroup has particular economic, social, political, cultural and geographical circumstances that require sensitivity. Yet, as negotiations have progressed the Commission has advanced a standardised set of liberalisation demands that reflect its broader trade objectives and negotiating mandate. ${ }^{6}$

1 European Commission Green Paper on Relations between the European Union and the ACP countries on the Eve of the 21st Century - Challenges and Options for a New Partnership (COM (96) 570 European Commission, Brussels, 1996).

2 Roman Grynberg "Towards a North-South Monologue: A Pacific Response to the Green Paper on Relations between the European Union and the ACP Countries" (ECDPM Working Paper no 25, Maastricht, 1997).

3 In 1993 Colombia, Costa Rica, Guatemala, Nicaragua, and Venezuela lodged a dispute against the EU bananas regime. In January 1994 a panel held that the EU regime was GATT-illegal, but the EU vetoed its adoption under the GATT rules that required consensus adoption of panel reports.

4 For a summary of Dispute DS165 United States - Import Measures on Certain Products from the European Communities see <http://www.wto.org> (last accessed 27 November 2006).

$5 \quad$ WTO "European Communities - the ACP-EC Partnership Agreement Decision of 14 November 2001" (14 November 2001) WT/MIN(01)/15.

6 South Centre "State of Play in the ACP-EU Economic Partnership Agreement Negotiations" Trade and Development Programme Informal Note, 30 August 2006, 24. 


\section{A Stalemate and Mounting Dissent}

The ACP states have consistently voiced a series of political, conceptual and operational concerns. First, the EU insists on a concept of development that is driven by reciprocal free trade, irrespective of its potential to devastate many of the world's poorest countries. Second, the EU's agenda reflects its generic negotiating priorities at the expense of the ACP requirements for flexibility, asymmetry and protection of policy space. Third, the EU has dictated the nature, terms and configuration of regional integration in ways that allow it to divide and rule the regions and cuts across organic developments that are underway or proposed among ACP states based on SouthSouth cooperation. Fourth, the ACP governments lack the capacity to conduct complex negotiations within the time frame proposed. Fifth, the cost of implementing reciprocal trade liberalisation would cripple small economies unless very substantial additional funding was provided. Sixth, the EU has used the Cotonou Agreement and EPAs to secure negotiations on the 'Singapore issues' of investment, competition and government procurement that it failed to achieve in the WTO.

By late 2006 negotiations in the six ACP regions were more or less at stalemate. A report on the state of play prepared by the South Centre in Geneva concluded that: ${ }^{7}$

Given the current status of the negotiations and the significant amount of work yet remaining, it is

unlikely that the EPAs will be completed on time. Additionally, the potential social, political and

economic consequences of these agreements are still unclear. The pressure to finish on time will likely

work to the disadvantage of the ACP countries.

That concern is echoed in the resolution of the Joint ACP/EU Parliamentary Assembly of 23 November 2006. They observed that "in most regions the negotiations on [EPAs] have reached virtual deadlock in view of disagreements on what is understood by the 'development dimension', which should be central to discussions on EPAs". ${ }^{8}$ There were no firm and specific undertakings on financing of the development dimension from the European side. Nor was there any evidence of progress on the call from the ACP Council meeting in Port Moresby in May 2006 for a 'full and comprehensive' review, as mandated by article 37(4) of the Cotonou Agreement, that should "be all inclusive and consultative with all stakeholders including non-state actors and parliamentarians".

Among their long list of specific recommendations, the parliamentarians argued for EPAs that are devised and negotiated as development agreements, rather than trade agreements. They noted that "the waiver accorded by the WTO in Doha in 2001 to allow for preferential trade relations between EU and ACP was meant to last three years longer (until 2007) than the Doha Round negotiations (to be concluded in 2004) launched at the same time" and that WTO negotiations had

7 South Centre, above n 6, 24.

8 Resolution of the Joint ACP/EU Parliamentary Assembly on the review of EPAs negotiations, voted on 23 November 2006. 
been suspended in July 2007. They therefore urged the Commission "not to exert pressure and to take steps to ensure that in the event of negotiations not being completed by 1 January 2008 existing ACP exports to the EU should not be disrupted until the final settlement is reached". It should also examine all alternative possibilities, including non-reciprocal arrangements for ACP states that decide not to enter an EPA, as article 37(6) of the Cotonou Agreement provides.

Dissent even came from EU Member States. In October 2006 the United Kingdom's trade and development ministers were moved to write a joint open letter to Peter Mandelson, the European Trade Commissioner, and Louis Michel, the EU Development Commissioner, insisting that ACP countries must have as much time as they reasonably need to open their markets and have effective safeguards against unfair competition from European products. Mandelson responded to the mounting criticism with the platitude that the trade dimension of the talks "is creating inevitable anxieties, which the negotiator on the EU side is listening and responding to". 9

\section{B The Pacific Context}

The prevailing sense of inequity is especially poignant for the Pacific ACP states, most of who are Least Developed Countries (LDCs) or small island states. Since 1998 trade ministers and leaders from the Pacific Island Forum countries have repeatedly affirmed their commitment to gradual integration into the global economy. This has proved more rhetorical than real. Their stepping-stone strategy was to begin within the region. Yet implementation of the Pacific Islands Countries Trade Agreement (PICTA) on trade in goods is behind schedule. The sub-regional Melanesian Spearhead Group trade agreement between Fiji, Vanuatu, Solomon Islands and Papua New Guinea (PNG) also faces problems of commitment and implementation. Both agreements only cover goods. ${ }^{10}$ Only the three WTO members (Fiji, Papua New Guinea and Solomon Islands) really have any experience of such negotiations or their implications. Of the three others engaged in WTO accession (Vanuatu, Tonga and Samoa), the first two have completed the process only to put their ratification on hold due to concerns about the excessive commitments they have made. ${ }^{11}$

The factor that looms largest on the Pacific trade horizon is the Pacific Agreement on Closer Economic Relations (PACER), signed with Australia and New Zealand rather reluctantly in 2002. ${ }^{12}$

9 "UK Urges Brussels to Relent over New Trade Rules for Poor Nations" (16 October 2006) Financial Times London.

10 Parties to PICTA have agreed in principle to its extension to services and this process is underway in tandem with the EPA negotiations.

11 Vanuatu's Working Party report was accepted by the WTO membership in 2001 but the government declined to sign its protocol of accession; Tonga signed its protocol of accession in December 2005 and was to complete ratification by 31 July 2006, but deferred that decision for a year largely for internal political reasons.

12 Jane Kelsey Big Brothers Behaving Badly. The Implications for the Pacific Islands of the Pacific Agreement on Closer Economic Relations (Interim report, PANG, Fiji, 2004). 
All the Pacific states involved in the EPA except Vanuatu are parties to PACER. This commits them all to begin negotiations for a regional economic integration agreement in 2011 or earlier for any party who begins formal negotiations for a free trade agreement (FTA) in goods with a developed country outside the region, such as the EU. As the bulk of Pacific islands trade is with Australia and New Zealand, such an agreement would have an enormous impact.

Despite a palpable ambivalence about the costs and benefits of free trade agreements, the Pacific ACP states are parties to the Cotonou Agreement and have committed themselves to negotiate an EPA with the EU. ${ }^{13}$ The Pacific ACP negotiating objectives, strategy and road map were published in a general form in August 2004. ${ }^{14}$ This proposed two levels of agreement: a master or umbrella agreement that set out the principles to govern the EPA that all Pacific ACP states could sign; and a series of subsidiary plurilateral agreements on goods, services, investment, fisheries, tourism and possibly more. The negotiations were formally launched on 15 September 2004 with a Joint Road Map that set out the principles, processes and general content for the negotiations. ${ }^{15}$ Over the next two years there were a number of meetings, but little progress.

In June 2006 the Pacific ACP negotiators finalised the first draft text for the Pacific EPA and discussed it informally with EC officials in July. ${ }^{16}$ The text contains an unusual combination of orthodox trade liberalisation and creative development-oriented initiatives, both of which would operate within an export-driven economic model. They are housed within an equally unorthodox structure. The secrecy surrounding the EPA negotiations makes it impossible to compare drafts from the different ACP regions, although a number have been leaked. ${ }^{17}$ From the information available it is clear that the architecture and content proposed by the Pacific is quite unique. ${ }^{18}$ Indeed, the text is so unorthodox and, in places, provocative as to suggest they do not expect to reach agreement with the EU. There appears to be no alternative text in the drawer. In that situation, the Pacific states would settle for the General System of Preferences (GSP) and Everything But Arms arrangements that are available to all developing and least development countries respectively.

13 For a discussion of the background to Pacific participation in the EPA negotiations and its implications see Jane Kelsey A People's Guide to the Pacific's Economic Partnership Agreement (Suva, World Council of Churches Pacific Office, 2005).

14 Pacific Islands Forum Secretariat The Pacific ACP-EU Partnership. The Way Forward (Pacific Islands Forum Secretariat (PIFS), Suva, 2004).

15 Pacific ACP-EU Joint Roadmap, 15 September 2004.

16 The draft text has not been officially released, but it can be viewed on $<$ http://www.bilaterals.org $>$ (last accessed 27 November 2006)

17 These texts and related documents can be found on $<\mathrm{http}$ ://www.bilaterals.org $>$.

18 For a discussion of the various regional approaches, see South Centre, above n 6. 


\section{THE DRAFT PACIFIC EPA TEXT}

The following analysis examines the structural and operational aspects of the draft text, then its substantive chapters.

\section{A Operational Provisions}

The Pacific text does not contest the basic premise of the Cotonou Agreement that global economic integration through trade liberalisation is a vehicle for sustainable development and poverty eradication; it would be impossible to do so and still play the game, even if some Pacific negotiators have reached such a view. However, the negotiators have reconfigured the standard structure of free trade agreements by integrating the liberalisation and developmental dimensions to provide for an interactive rather than linear and reductive relationship. The text also contains sectoral chapters on agricultural and tourism development that combine provisions normally found in chapters on investment, services, subsidies or sanitary and phytosanitary measures.

\section{Structure}

Core principles are set out in chapters 1 and 2. Institutional mechanisms are established in chapters on the institutional framework (Chapter 3), trade facilitation and promotion (Chapter 4), financing mechanisms (Chapter 9), consultation and dispute resolution (Chapter 10) and final provisions (Chapter 10). Substantive chapters cover agricultural development (Chapter 5), trade in services (Chapter 6), tourism development (Chapter 7) and investment promotion and protection (Chapter 8). Significantly, the main text provides only a 'framework' for economic and trade cooperation on goods (article 1.2(2)(a)), with liberalisation commitments and related provisions to be undertaken in Partnership Agreements on goods, fisheries or any other subject agreed to. All parties would be signatories to the EPA. Any rights and obligations under sectoral Partnership Agreements would be adopted separately and their terms would take precedence over the EPA.

Locating liberalising commitments on trade in goods in a separate plurilateral agreement is designed to limit the exposure of Pacific ACP states under PACER. As mentioned above, individual parties to PACER that begin negotiations for a GATT Article XXIV agreement on trade in goods would trigger 'consultations with a view to negotiations' for a free trade agreement between themselves and Australia and New Zealand.

As of June 2006 the governments of Fiji, PNG, Solomon Islands, Samoa, Vanuatu, Tonga and possibly the Cook Islands were considering negotiating with the EU on goods. ${ }^{19}$ It is not clear why. Only Fiji and PNG have any significant trade with the EU, and most of Fiji's trade is caught up in separate discussions over sugar. Any benefits for goods exports beyond what is already available under the GSP would require the European side to accept flexible rules of origin and customs requirements, which seems unlikely.

19 Minutes of the Pacific ACP Trade Ministers Meeting, Nadi, June 2006. 
The second nominated Partnership Agreement relates to fisheries. ${ }^{20}$ This is necessary because the Federated States of Micronesia, Kiribati and Solomon Islands already have bilateral fisheries agreements with the EU that they want to retain. The Pacific ACP governments have agreed that any Multilateral Fisheries Agreement must deliver benefits over and above those contained in the bilateral agreements. In November 2006 the Pacific Islands Forum Secretariat and the Forum Fisheries Agency were instructed to consult with regional stakeholders, especially the private sector, and propose ways to improve the overall competitive advantage of the Pacific ACP states in the international tuna trade. They are expected to propose measures for inclusion in a fisheries agreement that can provide opportunities for higher access fees and improve local benefits through a closer cooperation and integration of trade-related measures, fishing access arrangements and investment measures.

\section{Principles and objectives}

The development friendly principles and promises of the Cotonou Agreement are incorporated and expanded upon in the objectives and principles of the draft Pacific EPA. Key guiding principles include the intrinsic linkage of all parts of the agreement, which would have the effect of conditioning liberalisation on the supporting structures and funding; recognition of diversity and flexibility that reflects the circumstances of individual Pacific ACP states; and recognition that the EPA should not undermine the Pacific's own integration arrangements.

There is also a creative attempt to operationalise article 37.6 of the Cotonou Agreement that offers parties who choose not to enter a Partnership Agreement on goods the prospect of "a new framework for trade which is equivalent to their existing situation and in conformity with WTO rules". The obvious alternatives are the GSP for developing countries and Everything But Arms for the LDCs. ${ }^{21}$ The problem is that some Pacific states that are small vulnerable economies but not LDCs could receive worse access under the GSP than they have at present. Article 2.2 of the text requires the EU to provide a special equivalent scheme for those states or pay them compensation.

Article 2.3 addresses the fact that a majority of Pacific ACP states are not WTO members. The EU is expected to extend to their goods and services the MFN treatment they would receive if they were WTO members. This is not as progressive or risk free as it appears. The benefits of MFN mean very little in practice, because those countries have negligible current or potential trade with the EU.

20 A draft text was endorsed in principle by the Pacific ACP ministers in November 2006, but is not available at the time of writing. "Trade and Fisheries Ministers Endorse Draft Fisheries Partnership Agreement to Negotiate with EU" (14 November 2006) available at <http://www.bilaterals.org> (last accessed 1 February 2007).

21 For a comprehensive discussion of these alternatives see Sanoussi Bilal and Francesco Rampa Alternative (to) EPAs. Possible scenarios for the future ACP trade relations with the EU (Policy Management Report 11, European Centre for Policy Development Management, Maastricht, 2006). 
In return, they implicitly concede the critical argument that non-WTO members should not be subject to onerous and inappropriate WTO-based rules.

\section{The institutional framework}

Decision-making power is vested in three layers of joint bodies. Political leadership would come from a Partnership Council made up of European Council and Commission members and trade ministers from the Pacific parties. They would meet two-yearly to consider major issues and supervise implementation. Decisions would require consensus. Direct oversight of implementation and coordination would rest with a Partnership Committee comprised of representatives of the European Council and Commission and Pacific governments' senior officials. They would meet at least once a year and make decisions by consensus. Separate Special Committees would carry out the responsibilities set out in the chapters on agricultural development, services and tourism. The sectoral Partnership Agreements (on goods and fish) would also have Special Committees limited to the parties to those agreements. Again decisions would be by consensus. ${ }^{22}$

Viewed in the abstract this arrangement seems sensible and reasonably efficient. Yet it would vest trade ministers and officials with authority over policies that have multiple social, economic, cultural and developmental dimensions and are properly the responsibility of national parliaments. As explained below, the substantive chapters of the text empower these trade representatives to approve development strategies in agricultural development, services, tourism and trade facilitation. The strong likelihood that their meetings, documents, reports and decisions would be confidential, just like current negotiations and Pacific Islands Forum meetings, would shield them from effective scrutiny by Members of Parliament, citizens and other non-state actors.

The text could have addressed concerns about democracy and sovereignty by providing for active involvement of parliamentarians and non-state actors in decisions that directly affect the lives and livelihoods of their people and country. But political engagement is limited to the symbolic $\mathrm{ACP} / \mathrm{EU}$ parliamentary assembly. Likewise, article 1.4 reiterates the recognition in article 4 of the Cotonou Agreement of the complementary role and potential contribution of non-state actors to the development process, but it makes none of the associated commitments to consultation, financial resourcing, participation in implementation and capacity building. ${ }^{23}$

22 The following discussion centres on issues for the Pacific, but a new institutional structure could also pose problems for the EU. It is unclear who would represent the European side and the proposal effectively dilutes the role of the Commission. The relationships between the EU Commission, EU Council, Member states and different directorates are a complicated and sensitive issue.

23 This negates the recent rapprochement from Forum Secretariat officials and some political leaders towards civil society. For example, in June 2006 Fiji's Trade Minister Kaliopate Tavola opened the meeting of civil society organisation on the EPAs in Nadi, and the Forum's director of trade policy Roman Grynberg facilitated an open dialogue with trade officials from the various Pacific ACP governments. 
The text is more solicitous about national sovereignty. A number of provisions (notably article 1.4) assert the right of the Pacific parties to determine the development principles, strategies and models for their economies and societies "in all sovereignty". This echoes the language of article 4 in the Cotonou Agreement. Yet the assurance seems illusory. The substantive chapters propose that national and regional strategies would be subject to approval by a joint body of EU and Pacific trade officials. If the Pacific were genuinely in control it is not clear what role those joint committees would play; if the committees do have authority, there is no sovereign control over the Pacific's development. While the requirement that decisions must be made by consensus would ensure the Pacific parties do not lose control, so long as none breaks ranks, it could equally produce a stalemate and encourage the EU to broker deals within individual Pacific states behind closed doors.

Existing Pacific regional organisations and programmes would be used to implement the agreement, where appropriate. The Forum Secretariat is responsible for documentation, administrative support to reviews, negotiations, finance and technical assistance, and liaison. While the wording suggests the Secretariat would not control all the regional processes, other regional organisations have varying levels of competence and the relationship among them is often dysfunctional. $^{24}$ Involvement of the South Pacific Tourism Organisation or the South Pacific Regional Fisheries Management Organisation would clearly be limited to their areas of direct responsibility.

It seems inevitable that the Forum Secretariat will accumulate even greater power and resources. This is likely to exacerbate existing disquiet among Pacific Islands governments over the centralisation of power in the Secretariat, especially given its close relationship with and financial dependence on Australia and New Zealand. The Europeans' insistence on running the EPA negotiations and directing funding through the regional body has contributed to these tensions. Making that relationship permanent would have three effects: the trade-driven model of development would dominate the Forum's activities to an even greater degree; national governments with poor capacity, and their citizens, would become even more distanced from the seat of power; and the diluted role of Australia and New Zealand in the Forum's activities would produce new political dynamics. Already there are moves to strengthen coordination between Australia, New Zealand and the EU, in line with Europe's new "Strategy for a Strengthened Relationship with the Pacific". ${ }^{25}$ Their joint proposal for a roundtable on regional integration in 2006 was interpreted by

24 See A V Hughes "Strengthening Regional Management: A Review of the Architecture for Regional Cooperation in the Pacific" (PIFS, Suva, 2005).

25 European Commission "Strategy for a Strengthened Relationship with the Pacific" $<$ http://ec.europa.eu/comm/development/> (last accessed 6 August 2006) 
Pacific Islands officials and politicians as a new alliance of old colonial powers seeking to coordinate their assault on the Pacific. ${ }^{26}$

\section{Financing}

There are two other significant operational proposals in the draft text. Chapter 4 on Trade Facilitation and Trade Promotion is presented as a centrepiece of the "framework" (as opposed to 'liberalisation') agreement on goods. The Pacific governments have long insisted that they cannot engage effectively in international trade without funding to improve their ability to meet international standards, modernise their customs systems and promote products in overseas markets. Funding from Australia and New Zealand for a front-loaded Regional Trade and Facilitation Programme was part of their price for agreeing to PACER and major arguments ensued about the amount involved. The priority for support under the EPA is on agriculture and fisheries and products of "particular export interest" that the Pacific parties list in an annex. There is also a special focus on biosecurity regulation and practice.

The Partnership Committee of senior officials would develop a detailed trade facilitation and promotion programme for each party. Funding for this would be additional to any other technical or financial assistance the Pacific governments receive (from anyone), although they would attempt to coordinate their various trade facilitation and trade promotion programmes to minimise duplication. The Pacific governments have always sought to secure as much funding as possible from every source and to minimise active coordination of donor countries and agencies.

This initiative hinges on the funding mechanisms in Chapter 9, as does almost everything else in the agreement: implementation of the sectoral strategies, funding the institutional process, and meeting the costs of adjusting to the economic and social impacts of liberalisation under the EPA. This funding relies on the principle of 'additionality', meaning the EU and its Member States would provide extensive new "adjustment and trade development assistance" to "ensure" full implementation of the EPA and achievement of the Pacific's development goals. The amounts of current funding and the first five years of additional funding would be specified in Euros, with a commitment to successive five-year funding cycles that maintain the same real value.

The text proposes a range of funding options, including grants, budget support, loans, guarantees and shareholdings. These would be applied to diverse projects and programmes covering structural adjustment and diversification of agriculture, sectoral policies and reforms, capacity building, stabilisation of export earnings, budgets and balance of payments, and more. Eleven new facilities would be created, relating to different aspects of the EPA: trade facilitation and promotion; agriculture; service provider training; services regulatory adjustment assistance; tourism; SME financing; micro-financing; legal assistance; fiscal adjustment; structural adjustment; and fisheries.

26 Discussed in Jane Kelsey "Regionalism: An Opportunity or An Imposition on Fiji" (paper to a Workshop on Globalisation and Challenges to Fiji's Diplomacy, University of Fiji, Lautoka, 22-24 June 2006). 
An equally wide range of local and national government, private sector, NGO and community organisations would be eligible to receive funds, as would financial institutions, and regional and international organisations and institutions. Contracts for programmes and projects under the EPA would be reserved for Pacific people or companies, unless there were special circumstances. Supplies should likewise originate from the Pacific parties.

The allocation of funds provides another example of the tensions between trade and non-trade priorities, and sovereignty and shared authority. The political decision over funding priorities would be made by the Partnership Council of ministers, which would conduct 5-yearly reviews. Funding would be based on the Pacific parties' development objectives, strategies, policies and priorities. However, it would be allocated to particular projects and programmes by a new "independent" Authorising Authority, with its own governing body of 12 development and financing experts from the EU and Pacific parties, plus a CEO and secretariat. The new bureaucracy would prepare multiyear plans, authorise co-financing with other funding bodies and provide advice and assistance to eligible beneficiaries.

\section{Dispute settlement}

Chapter 10 on consultation and dispute settlement attempts to address the cultural, financial and practical defects in standard dispute mechanisms. Processes are expected to reflect relevant Pacific cultural values and customary procedures. Some aspects of the EPA may be excluded from the dispute mechanisms, such as the consultative approach proposed for tourism. Where disputes can be pursued in the WTO or the EPA, the decision on the forum should recognise that some Pacific parties are not WTO members, as well as considerations of cost and convenience.

Three avenues for resolution are proposed: bilateral consultations; consultations within the Partnership Committee; and arbitration. A legal aid fund would provide support to Pacific parties, except to bring vexatious cases. Where the EU is held in breach it is expected to pay temporary compensation while it takes action to comply and to face either withdrawal of benefits or pay monetary compensation to the value of the breach where it fails to comply. Where a Pacific state is found in breach, the EU must take into account the problems in adopting or implementing remedial measures and the need for longer time to comply.

\section{B Substantive Provisions}

The substantive chapters of the draft text cover agricultural development, trade in services, tourism development and investment protection and promotion, plus the separate goods and fisheries agreements. Those on agriculture and tourism are quite unorthodox, pursuing marketdriven development rather than pure liberalisation. The services chapter and goods agreement take a standard liberalisation approach with a low level of creativity. The investment chapter was blank in the initial text, but the two versions that subsequently emerged graft a range of rights and obligations of states and investors onto standard investment protection and promotion provisions. 
The sum is controversial and conceptually incoherent, but sufficiently heretical for the EU to reject almost every element.

\section{Agricultural development}

Chapter 5 is about agricultural development, not liberalisation of trade in agriculture. Its key objectives are to promote sustainable development of agriculture through increased production, productivity, processing and trade, especially in higher value products.

The most incendiary objective is article 5.1.2(d) to "assist in the reform of laws, including laws relating to land tenure and government policies and programmes" that will facilitate increased agricultural production, productivity and trade. "Enabling policies" under article 5.4.2 would require every Pacific party to "endeavour to strengthen local institutions and enact policies and legislation that provide for equitable and secure access to ownership and control of natural resources, particularly land". In other words, the EPA would become a vehicle to promote changes to land laws and ownership of natural resources. There is no assurance that the people would be actively involved in framing these agricultural development strategies, no mention of constitutional protections for land rights in many of the islands, and no recognition of competing social, cultural, spiritual and environmental considerations. Further, the reference to agricultural production, productivity and trade clearly envisages land reforms that promote larger-scale industrial agriculture. While the reference to 'equitable and secure access' could be read as referring to the interests of ordinary people, it seems more likely to mean security of larger-scale holdings for individuals and companies from the Pacific and offshore.

Each Pacific party and the region would develop an Agricultural Development Strategy with a statement of objectives, expected outcomes, plan of action, timetable and budget. It would also contain recommendations on improving agricultural production, competitiveness, processing, sales and improving export opportunities, and addressing weaknesses. This exemplifies the sovereignty dilemma raised earlier. Article 5.2 stresses that each Pacific party would "retain full control over its development strategy". Yet article 5.3 says each nation's strategy and the Pacific regional strategy would be "submitted to the Partnership Committee [of senior officials] for its adoption". Under article 5.7 the Committee would review the strategy every two years and each Pacific party would then decide what revisions it considered necessary or desirable.

The chapter also illustrates how the market-centred development model underpins the Pacific's approach, despite the innovations. These agriculture development strategies would doubtless contain many positive proposals to enhance production and the ultimate decision would remain with governments. But the effect of specifying and privileging an industrial and export-driven approach to agricultural development would be to lock every Pacific island that signed the EPA into that model. The extent to which parties could deviate would be constrained by the commitment to develop a regional strategy for agricultural development. 
Industrial agriculture centres on cash cropping through larger scale industrial production, growing crops for export and importing other foods. Food security becomes notoriously difficult when the limited resources of small countries are focused on producing export cash crops. The national and regional strategies are also required to consider and make recommendations on food security and "support for grassroots development activities, rural cooperatives, initiatives of subsistence farmers" and providing rural credit. But these are subcategories within the dominant industrial cash-cropping model. There is no guarantee of a balance between subsistence food production and industrial agriculture or that duty free imports would be prevented from threatening these objectives. Given that these strategies are also meant to include land reform, the proposal seems quite detached from reality.

With specific reference to agricultural exports, Chapter 4 on trade facilitation provides several innovative provisions to reduce sanitary and phytosanitary barriers. These tighten the rules on measures available to the EU and allow the Pacific parties to challenge the exclusion of their exports on spurious grounds using a cheaper and more tailor-made disputes process than the WTO. The EU would have to pay compensation to individual Pacific exporters for losses they suffered where there was no scientific proof to support a ban on their product. If the EU proposed to restrict or prohibit the import of products that were listed as being of export interest to the Pacific, it would first have to consult the countries that might be affected and conduct a joint study of the scientific evidence to support the measure. A contact point would be established for the exchange of information of such measures.

This proposal was prompted by the devastating ban imposed by several European states, among others, on imports of kava from Vanuatu, Fiji and several other islands in 2001. Although Fiji was a WTO member it was too expensive to bring a complaint in the WTO. Even if they had done so and won, there would have been no compensation for the losses they, let alone non-WTO members, had incurred. However, this is a double-edged sword. Even though the target is Pacific exports to the EU, it would effectively pre-empt a Pacific state from invoking the precautionary principle where it lacks scientific proof that imports will cause harm and the capacity to conduct such research.

Sugar is covered in a separate article, which attempts to secure the benefits and value that Pacific parties (namely Fiji) enjoy under the Sugar Protocol for the long-term. The Agricultural Development Strategy would include measures to enhance the productivity of the sugar industry and support development of higher-value sugar products and diversification into other crops. Implementing the strategy and projects and providing short-term income support to farmers would be funded through Chapter 9 mechanisms. It is not clear how this provision relates to the agreement on goods, which includes agricultural products, and the GATT article XXIV requirement that a goods agreement covers 'substantially all trade'. 


\section{Tourism development}

The tourism chapter follows a similar approach, with development of a regional strategy to maximise the potential for economic growth, job creation and government revenues in ways that are environmentally sustainable and culturally appropriate. The objectives and principles are very community-, culturally-, environmentally- and development-oriented and are modelled on the Agreement on Trade, Development and Cooperation between the EU and South Africa. ${ }^{27}$ However, the stated aim of the EU-South Africa tourism provision is to "strengthen development of a competitive tourism industry"; the Pacific's is to 'maximise the potential offered by the tourism sector' by blending internally focused development and externally oriented services and investment liberalisation.

This exposes the intrinsic contradictions in the Pacific EPA once again. Enabling policies to promote tourism include promoting foreign and domestic investment "consistent with local economic and social objectives" and helping local operators access global web systems. Yet liberalisation of trade in services aims to promote economies of scale and competitiveness that favour larger scale provision of tourism operations, which are usually integrated on a global scale and within networks of transnational firms. It is unrealistic to believe that smaller local tourism providers, especially community-based initiatives, can thrive in this environment. Experience with foreign and larger scale tourism operations in the Pacific islands shows how difficult it is to maintain environmental protections, cultural integrity and indigenous land rights and ensure domestic reinvestment rather than remittance of profits. ${ }^{28}$ Although the chapter's 'enabling strategies' do not directly mention land reform that is an obvious policy target when promoting foreign and domestic investment in tourism. Indeed, the EU's requests of PNG and the Solomon Islands in the WTO services negotiations included the removal of restrictions on foreign investment in land. ${ }^{29}$

Operationally, the South Pacific Tourism Organisation would develop a Regional Tourism Plan that, like the Agriculture Development Plan, would set out objectives, outcomes, plan of action, timeframe and budget. It would make recommendations on planning, marketing, training, funding, infrastructure and more. The regional plan would be submitted to a Tourism Partnership Committee comprising EC and Pacific officials for 'consideration'. They would 'decide whether to adopt the plan as submitted or in a modified form' and review, and if necessary revise, the plan every two

27 Available at <http://www.tralac.org > (last accessed 27 November 2006).

28 See for example Claire Slatter "The Con/Dominion of Vanuatu? Paying the Price of Investment and Land Liberalisation - a case study of Vanuatu's Tourism Industry" <http://www.oxfam.org.nz $>$ (last accessed 27 November 2006).

29 EC "GATS 2000 Request from the European Commission and its Member States to Papua New Guinea" and "GATS 2000 Request from the European Commission and its Member States to the Solomon Islands" $<$ http://www.gatswatch.org $>$ (last accessed 27 November 2006). 
years. Further liberalisation might include eliminating restrictions on services and investment, including improved access for European tourism operators. It might also provide for better access to the EU for Pacific tourism professionals and marketing agencies. The costs of implementation would come from the financial facility in Chapter 9.

Where the plan recommends further liberalisation of trade in services, the Pacific parties or EU 'shall endeavour' to implement these during future reviews of the services chapter. This Plan would be regional. There is no parallel to the national level agriculture development strategies and no assertion that countries would retain full control. Presumably, this is because existing practice involves developing a Regional Tourism Strategy. However, the obligations relating to liberalisation of services and investment make this a very different exercise, especially as the decision making authority of the Partnership Committee of EC and Pacific officials is more directive than for agricultural development. The saving grace is that there is no binding enforcement of the commitments in this chapter or the tourism plan.

\section{Services}

In stark contrast to agriculture and tourism, the chapter on services follows the standard liberalisation model of the General Agreement on Trade in Services (GATS). Parties would liberalise market access and national treatment through the four modes of supply (cross-border, consumption abroad, foreign investment and temporary movement of services personnel) for service categories listed in each country-specific schedule. A number of development provisions are added. Programmes for capacity building and training would be designed for a list of services that Pacific states could supply to the EU or other countries, funded under Chapter 9. This list could be reviewed and revised periodically by the Partnership Committee of senior officials.

The implications for domestic services are significant. National treatment commitments would remove the ability of the Pacific parties to provide preferential treatment to their local people and firms who supply those services. Market access liberalisation would, inter alia, prohibit "economic needs tests" that allow foreign participation only when no appropriate local providers or workers are available, requirements to enter into joint ventures or limitations on the percentage of foreign ownership. These and similar measures are often used by developing countries to prevent their domestic services from being hollowed out by foreign players, especially in the more lucrative parts of the market. There are particular risks that domestic firms will collapse in the face of competition and the foreign firms then depart. The requirement for joint ventures or a minimum level of local ownership has been a partial protection against that risk.

There is an unsuccessful attempt to carve out public services, which are described as "activities forming part of a system of social security or public retirement plans or the public provision of health, education or water services". This wording assumes those services are 'publicly provided', whereas they are increasingly provided by private firms. The more appropriate wording would be "the provision of public health, education or water services". The provision also ignores the many 
other aspects of public services that are not mentioned, such as sanitation, media, electricity and telecommunications. Consistent with the pro-liberalisation tenor of the chapter, the drafting notes describe this exemption as a response to 'NGOs and others' that could be traded away.

Following standard GATS methodology, each Pacific party can limit its exposure to these obligations through its services schedule. However, these are extremely complex legal documents of which most Pacific governments have very little experience. The excessive commitments that Tonga and Vanuatu made in their WTO accessions show how easy it is to make them and how hard they are to change. That risk is compounded by the secrecy that surrounds their preparation. Although each party's level of exposure is flexible, article V of GATS requires such agreements to have 'substantial sectoral coverage' to be achieved within a 'reasonable' time. There is some leeway for developing countries, but its extent remains untested in the WTO.

The sovereignty dilemma resurfaces in articles 6.1.3 and 6.7, which assert that all parties retain the right to regulate and introduce new regulations to meet their national policy objectives and that the agreement shall not be construed "in any way" to prevent the parties for regulating. Again, the reassurance is deceptive. The critical issue is not simply the right to regulate, but to regulate in the way that national parliaments consider appropriate. If a Pacific parliament adopts measures that breach its country's commitments and a dispute results, it could be required to withdraw the regulations to avoid retaliatory trade sanctions.

The draft offers two solutions to this dilemma. One allows Pacific parties whose service sectors are threatened by liberalisation under the EPA to use or maintain as safeguards the measures they had promised to abandon. However, safeguard action would be temporary and must not discriminate against the EU. Second, where Pacific parties lack an appropriate regulatory regime for services they have promised to liberalise they can have more time to establish one, provided they take reasonable steps and are not just foot-dragging. Where a government receives financial and technical assistance to establish a regime, however, it must implement its commitments within three years of that programme starting. A few consultants and a few thousand Euro could negate that protection very easily.

It is not clear why they have taken such a pro-liberalisation position on services when there is no evidence that such commitments result in more foreign investment or better services. For most developing countries the quid pro quo is access for their service workers to the other party. Indeed, this has been the primary demand made by Pacific states in the WTO, of Australia and New Zealand and in discussions on the EPA. While the text aims to facilitate more transparent reciprocal movement for periods up to three years, that is limited to skilled and semi-skilled workers, such as professionals, technicians and executives. The actual categories would be specified in an annex. There is no reference to entry for low-skilled services workers, although the text does not explicitly exclude them. 
It is difficult to judge whether this chapter reflects pragmatism, the advice of consultants or a lack of understanding of the implications. Its inclusion is especially puzzling as there is no requirement for a services chapter in the EPA. The Cotonou Agreement makes services liberalisation contingent on ACP states having experience with services agreements, a standard that Pacific states manifestly have not met.

\section{Investment}

An IPPA+ (Investment Promotion and Protection Agreement + more) has always been integral to the Pacific's strategy for the EPA. This caused some disquiet in the ACP, which had been instrumental in blocking the EU's promotion of investment rules in the WTO on the grounds that they restrict the sovereign right of states to regulate foreign investments. That victory has been eroded by the growing number of bilateral investment treaties (BITs) and free trade agreements that include both investment chapters and rights of establishment as a mode of trade in services. For countries without such commitments, including most of the Pacific ACP states, the absence of multilateral rules means they can still say 'no'. Only three Pacific states currently have BITs with the EU: PNG signed treaties with Germany and the UK in the early 1980s and Tonga and Vanuatu entered IPPAs with the UK in 1997 and 2003 respectively. The inclusion of investment is therefore a major development. One consultant's report on investment was positive about the value of such an arrangement for the Pacific; ${ }^{30}$ a second was sceptical that it would make any difference to foreign investors' decisions. ${ }^{31}$

Aspects of the investment chapter are standard. Its definitions and coverage include logging permits, mining licences and concessions, land titles and leases and management contracts, but not portfolio investment and intellectual property rights per se. Full capital convertibility and repatriation of capital and profits are guaranteed. Investors have rights to market-based compensation for both direct and indirect expropriation. To avoid over-zealous use of the indirect 'takings' protection, ${ }^{32}$ governments retain the right to adopt bona fide and non-discriminatory regulatory measures that aim to promote and protect public welfare objectives, such as public health, safety and the environment. Pre-establishment rights are only covered if a party lists sectors that it has liberalised in an annex. Two other annexes limit the application of the investment rules using a negative list approach: one lists economic sectors (including services) that are excluded; the

30 David Forsyth Framework for EPA negotiations with the European Union: Investment Study (PIFS, Suva, 2003).

31 A V Hughes "Promoting Investment in the Pacific through an ACP-EU Agreement" (Report to PIFS, December 2004).

32 For the potential effect in the Pacific see Jane Kelsey A People's Guide to PACER. The Implications for the Pacific Islands of the Pacific Agreement on Closer Economic Relations (Suva, Pacific Network on Globalisation, 2004) 34-36. 
second applies standstill to non-compliant measures that are listed and automatically covers all local government measures.

The draft text attempts to mitigate both the risks of mistakes in preparing annexes and the loss of policy space and to maximise the potential benefits. Indeed, the approach is so unorthodox that the Pacific ACP negotiators cannot expect to reach agreement with the EU. For example, the text uses a standard national treatment provision that covers managing, operating, expanding or selling an investment "in like circumstances", but defines 'like circumstances' to include the effects on third persons and the local community, impacts on the environment, the sector involved, the aim of the government measure that is of concern, the regulatory process applied in such matters and other relevant factors.

In addition, articles 8.11 to 8.18 set out a long, innovative list of obligations and duties for foreign investors and investments. These include the conduct of environmental screening and social impact assessments, acceptance of the precautionary principle, upholding human rights and core International Labour Organization standards, meeting corporate governance standards and not offering bribes. Home or host states could bring proceedings to revoke the rights of an investor who persistently breaches or fails to comply with key post-establishment and governance obligations. The failure of investors to meet their pre-establishment obligations could be used to mitigate or offset actions by governments that were challenged by an investor. Where domestic law allows, the host state or a private person or organisation could even initiate a suit against an investor for damages arising from a breach of this chapter.

Parallel obligations and rights are proposed for host states in articles 8.19 to 8.28 , including procedural fairness, public disclosure and high levels of environmental, labour and human rights protection. Home states of investors are required to facilitate and promote investment, criminalise offshore bribery by their nationals and ensure their legal rules allow court actions to be brought against their investors for acts done or decisions made in the Pacific states.

This agreement would supersede existing international investment agreements involving EU states and individual Pacific parties. ${ }^{33}$ A separate two-tier dispute settlement body is proposed, along with a complex institutional framework. Funding would be provided under Chapter 9 for a Legal Aid Assistance Centre and for support to promote foreign investment and its benefits. Complementing that are moves to enhance access to finance. The European Investment Bank would set up a branch in a Pacific state (which is currently proposed for Sydney) and develop lending facilities that are geared towards small and medium enterprise operations that are unable to source funding from elsewhere. An Investment Guarantee and Insurance Agency would be established, in line with an all-ACP proposal. Pacific states would also receive assistance to use the proposed new mechanisms for micro-financing and small and medium enterprises.

33 This is problematic as BITs are within the competency of Member States, not the Commission. 


\section{Goods}

The separate plurilateral agreement on goods follows a standard GATT format and content, with a few deviations. Article 6 on rules of origin defines "goods" to include agricultural products. Liberalisation would be asymmetrical. The EU must provide immediate duty free, quota free access for Pacific exports. Pacific parties would reduce customs duties on imports from the EU according to schedules of timetables and tariff lines that vary for LDCs and small island states, and apply a standstill to customs duties on all products except those listed in an annex of exempt import or export prohibitions or restrictions. These would be progressively reduced or eliminated. Proposed rules of origin for Pacific exports follow a tariff heading rule at 6 digit level. They also cover fish caught within their 200 nautical mile exclusive economic zone by vessels of parties to the EPA or of non-parties where the fish are landed in a Pacific territory. The EU's rules of origin were not in the draft.

Articles 12 and 14 prohibit the use of anti-dumping or safeguard measures by the EU, while modifying WTO safeguard rules to make them easier for Pacific parties to use. Likewise, subsidies used by Pacific parties could not be challenged, while EU subsidies that cause or threaten serious prejudice to a Pacific party or material injury to its domestic industry could be. Procurement of goods by Pacific, but not EU, governments is excluded. An infant industry exception in article 16 would allow Pacific states to raise tariffs where imports from another Party (not just the EU) "retard materially the establishment of a domestic industry" in like or directly competitive products. This could apply for an initial eight years, or thirteen for LDCs and small island states, provided the industry had commenced production, and could be extended for up to 13 or 18 years respectively where there was evidence that this was needed for the industry to adjust to competition. The criteria for competitiveness might include a specific volume of export sales.

The institutional mechanism mirrors those in the EPA and funding relies on the financing facility in Chapter 9. The agreement would come into effect on ratification by the EU and (probably) 3 Pacific island countries, with provision for others to accede.

This highly asymmetrical text would have to meet the GATT article XXIV requirements that it covers substantially all trade and is implemented within a reasonable timeframe. However that formula is interpreted, it would be difficult to provide special treatment for sugar, as it is the second largest Pacific export to the EU after palm oil from PNG. Yet its status is ambiguous. The reference in article 5.8 in the agriculture development chapter to safeguarding the benefits and value of the Sugar Protocol implies some kind of special treatment, but sugar is not excluded from the definition of 'goods'.

The Partnership Agreement includes an optimistic compensatory mechanism for adjustment costs. Given the low level of trade between the EU and Pacific islands, except for PNG and Fiji, the direct fiscal and structural impacts would be minimal. However, the flow-on effects of a comparable arrangement with Australia and New Zealand under PACER would be potentially catastrophic and 
that would be triggered by negotiations on goods with the EU. ${ }^{34}$ The text requires the EU to provide resources to assist fiscal adjustment projects that arise from the EPA and "consequent" liberalisation, and structural adjustments that flow "directly or indirectly" from those commitments. The prospect of the EU agreeing to fund the impacts of trade liberalisation with Australia and New Zealand seems remote indeed.

\section{REFLECTIONS}

This draft text sets out the Pacific ACP states' wish list. It attempts to weaken the standard free trade rules to advantage the Pacific and includes creative proposals that could benefit particular countries and sectors. Equally, it operates within the controversial trade-driven development paradigm and offers commitments and concessions that have tangible risks and questionable benefits. This is only the starting-point for negotiations. Any final text will be much weaker because the EU will refuse to accept what it does not like. Most, if not all, of the innovations can be expected to disappear.

That was confirmed in a letter from the EC's lead negotiators to the chair of the Pacific negotiating team, Senator Kaliopate Tavola, on 20 October $2006 .{ }^{35}$ They said progress had been "inadequate". The negotiations were now "at the crossroads". The text would need substantial amendment to become a mutually-agreeable EPA. All parties had to respect the December 2007 deadline, so a redoubling of efforts was required to accelerate convergence towards a "common landing zone". The only acceptable aspect was its structure, pending some modifications. That included the separate annex on goods, provided all states were encouraged to sign.

The Commission's list of objections followed their ACP-wide position. There could be no standalone agreement on fisheries outside the EPA. Rules of origin must be uniform across all six regions with no asymmetry between the ACP parties and the EU. The inclusion of services and investment was welcomed, but their form should follow the non-paper on services and investment submitted to the Pacific (and Caribbean and East and Southern Africa regions) in accordance with the EU's liberalisation and investor protection policy. ${ }^{36}$ The terms and institutional mechanisms for investment rules and financing were set down in the Cotonou Agreement and could not be varied. The requests on temporary movement of labour were matters within the competence of Member States, although the Commission could facilitate dialogue. Funding for human resource

34 In anticipation, the November 2006 meeting of Pacific ACP trade ministers had agreed to appoint a Chief Trade Negotiator for the PACER negotiations. "PICs Call for Political Intervention in EPA Negotiations" (16 November 2006) <http://www.pacreip.org> (last accessed 1 February 2007).

35 European Commission "Deputy Director-General to Hon Kaliopate Tavola" (20 October 2006) TRADE/KFF D 12520.

36 EC "EPA Negotiations with Cariforum, Pacific and ESA on the liberalisation of trade in services and the right of establishment - Draft Title 'Establishment, Trade in services and e-commerce"' (7 November 2006) based on non-paper on trade in services (27 July 2006) MD 141/06. 
development and training should be addressed in the $10^{\text {th }}$ EDF regional indicative programme. The letter reiterated the EU's demands for inclusion of government procurement, competition policy and intellectual property, arguing that these had already been partly agreed in the Cotonou Agreement. In other words, the EPA should be a full-blown WTO+ free trade and investment agreement.

Moreover, WTO+ trade liberalisation remained the only acceptable vehicle for sustainable development and poverty eradication, even for the small, remote vulnerable islands of the South Pacific. The incorporation of development cooperation into the EPA text was 'not acceptable': the Cotonou Agreement provided a mutually reinforcing framework to address development assistance on one hand, and trade provisions in the EPA on the other. Costs associated with an EPA should be addressed through transition periods, bilateral safeguards and assistance from the $10^{\text {th }}$ European Development Fund. 'But we should not forget about the benefits. The EU believes that the [benefits] will in the end exceed the [costs] which is the reason why we pursue the EPA idea'.

The Pacific ACP trade ministers' response was rapid and sharp. Noting their significant differences over issues of development cooperation, EPA adjustment and services, Vanuatu's Trade Minister Hon James Bule said the "inadequate response from the EC can only be construed as reluctance on their part in seriously addressing the issues raised by the PACPS. But we must remain optimistic and maintain PACP solidarity and continue to drive home our positions". ${ }^{37}$ The focus of engagement with the European side would shift to the political level. A Forum Secretariat spokesperson observed that "the EU had clearly not responded well or favourably to the PACP submissions" with the only point of consensus being the architecture. He too urged Pacific ACP countries "to remain optimistic and maintain solidarity" in the critical final year of negotiations and capitalise fully on the opportunities presented by the upcoming review of the EPA process. ${ }^{38}$

Where to from here? The evidence suggests the Europeans do not intend budging from their hard line liberalisation agenda, despite internal criticism. By inviting the six ACP regions to draft the initial texts, the EU has drawn them into negotiations where they may seek to defend their text as it is savagely eroded. Further, as each region is negotiating separately, the EU can play off their concessions against each other. Some governments and regions may capitulate to EU pressure, probably from fear of losing aid funding. How many will depend on the political solidarity within and between the regions, pressure on ACP governments from below to say no to a bad deal and challenges to the Commission's position from within Europe.

Governments from the Pacific and other sub-regions have made it clear to the EU that they want to explore the alternatives foreshadowed under article 37.6 of the Cotonou Agreement during the

37 "PICS Call for Political Intervention in EPA Negotiations" (16 November 2006) $<$ http://www.forumsec.org $>$ (last accessed 1 February 2007).

38 "PICs Reminded to Maintain Solidarity in EPA Negotiation with EU" (15 November 2006) $<$ http://www.pacreip.org $>$ (last accessed 1 February 2007). 
scheduled review of the negotiations, because they see little to gain and much to lose from an EPA. The EU insists there are no viable alternatives. They have ensured that the review process takes a separate track from the negotiations and would not be completed until around March 2007. Nevertheless, ongoing paralysis within the EPA negotiations could create the space for discussing those options. In default of an EPA, the Pacific and other ACP states would fall back on the WTOcompatible preferences in the GSP and Everything But Arms. That outcome would also relieve Pacific parties to PACER of the need to commence negotiations with Australia and New Zealand. Freed from the pressure of an imminent negotiating deadline they would have more time to consider genuine development alternatives for the Pacific Island states that are not embedded in a controversial trade-driven development paradigm. 
